\title{
Global Research Trends in Robot Education in 2009-2019: A Bibliometric Analysis
}

\author{
Kaiqin Yang, Xin Liu, and Guang Chen
}

\begin{abstract}
With the continuous development of science and technology and the advent of artificial intelligence era, the practice and application of robot education are becoming more and more common. Educational robots have become an important educational resource in today's society, attracting the interest of teachers and researchers. Today, robot education is not only an important way to enhance students' digital competencies in the information society, but also a valuable tool for cultivating students' cognitive and social skills. This paper uses VOSviewer software to visually analyze the literature of robot education research in Web of Science for the past ten years. The research hotspots mainly focus on the cultivation of students' computational thinking, the teaching practice of robot education, the teaching tools of robots, and the environment.
\end{abstract}

Index Terms-Research frontier, robot education, visual analysis.

\section{INTRODUCTION}

With the development of the information society, traditional teaching resources can no longer meet the development needs of new talents. Robots have become an emerging educational resource for educational practice. In recent years, robotics has been included as a valuable educational resource in the development of technical and social skills. [1] Studies have shown that robotics education can enhance students' knowledge of subject knowledge, such as mathematics, biology, physics, geography, etc. [2]-[4]. Moreover, robot education is of great value in promoting students' social skills, programming skills, and computational thinking [5], [6]. Ana found that educational robotics can be integrated into the teaching-learning process through various practical approaches, one of which is its adoption as the main object of education [7]; a second approach would be as a means of learning; the third would be to use it to support learning developments.

However, there are still some difficulties in the development of current robot education. For example, there are currently no robot designs specifically designed for students of different ages. There are few specialized robotics courses in regular schools, and educational robots are rarely used as teaching tools. No country has included it in the curriculum. These activities are carried out during weekend after-school activities or summer camps [8], and robots are not integrated into school education.

Manuscript received September 30, 2019; revised March 30, 2020.

Kaiqin Yang and Guang Chen are with School of Education and Technology, Beijing Normal University, China (e-mail: 17610249581@163.com, guang@drgchen.com).

Xin Liu is with Preschool Education Institute, Beijing Normal University, China (e-mail: 1063452463@qq.com).
This study attempts to use the bibliometrics and information visualization tools to visualize the research frontiers and hotspots of international robot education, to inspire future robot education research.

\section{METHOD}

The Social Sciences Citation Index database in the Web of Science Core Collection (WoSCC) was retrieved online as the data source for this study. The retrieval topic was "robot*," the timespan was "from 2009 to 2019," and the document type was "article." The research field is limited to "EDUCATION EDUCATIONAL RESEARCH," "EDUCATION SCIENTIFIC DISCIPLINES," "EDUCATION SPECIAL," and 262 documents are retrieved.

Subsequently, the VOS viewer literature analysis software was used to carry out keyword co-occurrence analysis on the sample literature data to obtain a hot spot in robot education research.

Visualization software can produce node-link maps that allow us to intuitively observe the publication outputs, hotspots, and other aspects of a research field. In this study, the data were imported into VOSviewer v.1.6.13 and analyzed systematically. VOSviewer (www.vosviewer.com), developed by van Eck and Waltman, is a literature visualization software that has advantages of displaying cluster analysis results.

\section{RESULTS}

\section{A. Publication Year Distribution}

In the past ten years, international research on robot education has shown a gradual increase (Fig. 1). In 2019, a new research climax emerged, reaching 52 in number, which indicates that robot education is gradually attracting researchers.

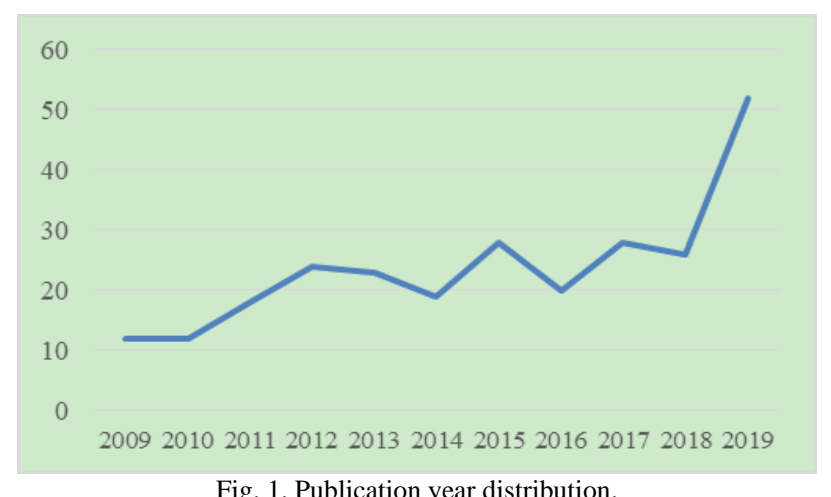

Fig. 1. Publication year distribution. 


\section{B. Country Distribution Analysis}

In the past 10 years, a total of 47 countries or regions have published SSCI papers on robot education, as shown in Fig. 2. Among these countries, the United States has published the largest number of papers in the past 10 years, with 77 articles (29.39 percent out of 262), followed by Taiwan (34, $12.98 \%)$.

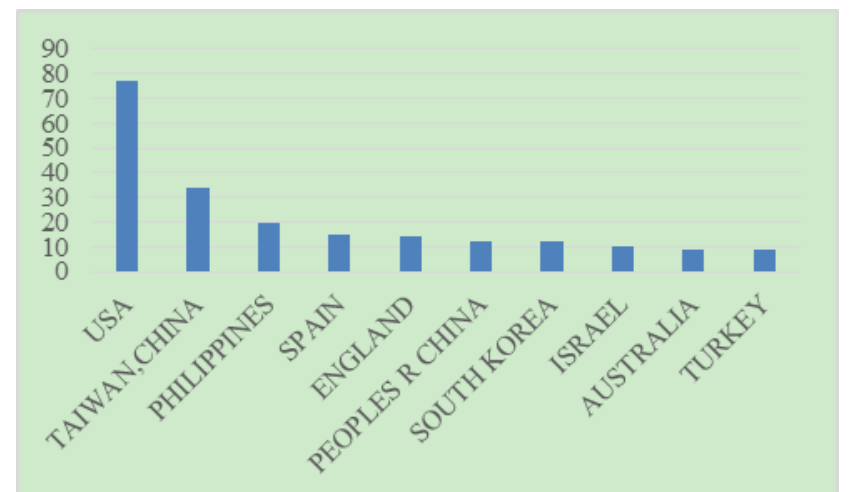

Fig. 2. The top 10 countries that published the largest number of articles.

Fig. 3 shows the trends in annual publications for each country from 2009 to 2019 . It is worth noting that the related research on robot education in the United States in recent years has shown rapid growth. Using VOSviewer software, we analyzed the network visualization of co-creation relationships between countries. In countries with only at least 25 documents, 10 countries have reached the threshold. As shown in Fig. 4, the United States and the United Kingdom are at the center of robotics research and work closely with Spain, Italy, Belgium, and the Netherlands.

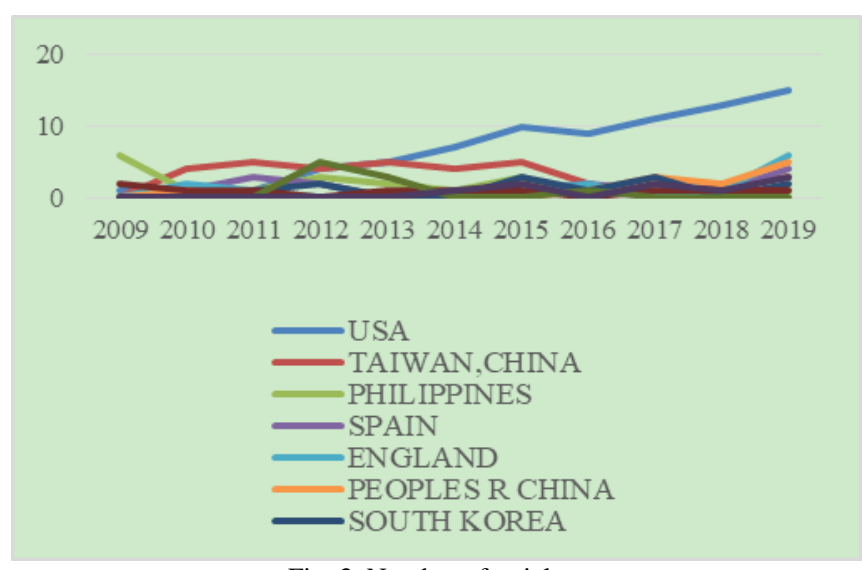

Fig. 3. Number of articles.

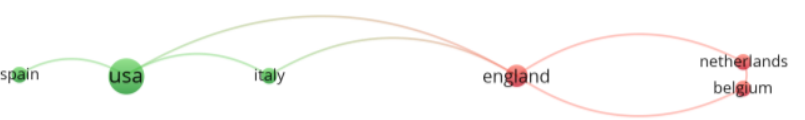

Fig. 4. Distribution of the country's co-creation relationship.

\section{Citation Analysis}

To some extent, the citation frequency of the article reflects people's attention to particular research work and demonstrates the development status and research hotspots in this field. Analyzing the research content of highly cited papers can help us understand what the research content with a strong influence in the research field is. After preliminary condition screening, a total of 262 documents were left.
According to the ranking of cited times, the paper takes the top five cited times as the research object to analyze. (Table I)

\section{1) Papers with high citations}

Cited references in this study refer to the number of papers cited in the statistical database. The five references cited most in this study are shown in the following table/appendix. The frequency of 5 cited references is above 85 . The highest frequency was 209 .

TABLE I: THE Most Cited 5 ARTICLES

\begin{tabular}{|c|c|c|c|c|}
\hline Number & Author & Article & $\begin{array}{l}\text { Publi } \\
\text { shed } \\
\text { Year }\end{array}$ & $\begin{array}{l}\text { Cited } \\
\text { frequency }\end{array}$ \\
\hline 1 & $\begin{array}{l}\text { Vavassori } \\
\text { Benitti, } \\
\text { Fabiane } \\
\text { Barreto } \\
\text { Joshua }\end{array}$ & $\begin{array}{l}\text { Exploring the } \\
\text { educational potential } \\
\text { of robotics in schools: } \\
\text { A systematic review }\end{array}$ & 2012 & 209 \\
\hline 2 & $\begin{array}{l}\text { J.Diehl, } \\
\text { Lauren } \\
\text { M.Schmitt, } \\
\text { Michael } \\
\text { Villano, } \\
\text { Charles }\end{array}$ & $\begin{array}{l}\text { The clinical use of } \\
\text { robots for individuals } \\
\text { with Autism Spectrum } \\
\text { Disorders: A critical } \\
\text { review }\end{array}$ & 2012 & 170 \\
\hline 3 & $\begin{array}{l}\text { Bers, MU; } \\
\text { Flannery, } \\
\text { L; } \\
\text { Kazakoff, } \\
\text { ER ; } \\
\text { Sullivan, A }\end{array}$ & $\begin{array}{l}\text { Computational } \\
\text { thinking and } \\
\text { tinkering: Exploration } \\
\text { of an early childhood } \\
\text { robotics curriculum }\end{array}$ & 2014 & 94 \\
\hline 4 & $\begin{array}{l}\text { Jara, CA; } \\
\text { Candelas, } \\
\text { FA; } \\
\text { Puente, ST; } \\
\text { Torres, F }\end{array}$ & $\begin{array}{l}\text { Hands-on experiences } \\
\text { of undergraduate } \\
\text { students in Automatics } \\
\text { and Robotics using a } \\
\text { virtual and remote } \\
\text { laboratory }\end{array}$ & 2011 & 88 \\
\hline 5 & $\begin{array}{l}\text { Potkonjak, } \\
\text { V ; } \\
\text { Gardner, } \\
\text { M ; } \\
\text { Callaghan, } \\
\text { V ; Mattila, } \\
\text { P ; Guetl, } \\
\text { C ; } \\
\text { Petrovic, } \\
\text { VM ; } \\
\text { Jovanovic, } \\
\text { K }\end{array}$ & $\begin{array}{l}\text { Virtual laboratories } \\
\text { for education in } \\
\text { science, technology, } \\
\text { and engineering: A } \\
\text { review }\end{array}$ & 2016 & 87 \\
\hline
\end{tabular}

Sort the retrieved articles according to the citation frequency, and get the top 5 articles cited. The most cited paper is "Exploring the educational potential of robotics in schools: a systematic review." [9]. The paper, published in 2012, reviewed scientific literature published between 2000 and 2009 on the use of robots in schools. Based on the summary and analysis of the relevant literature in the past, this paper discussed the subjects that schools teach through robots, how students evaluate learning, and whether robot technology is an effective teaching tool. The key problems in the field of robot education research and the hot issues in this field are revealed. In addition, the frequent citation of this paper is also related to the characteristics of the article. Due to its wide coverage of the knowledge and abundant information, review and critical papers are most easily cited [10]. This is due to the systematic collation, induction, and 
analysis of the review articles on the original literature of a certain discipline or field within a certain time range, which is prospective literature different from other research literature. Generally speaking, high-quality review articles will contain important content such as the development overview, research hot spots, and future development direction of a certain field of study, which is valuable literature materials for researchers in each relevant field to study and analyze first.

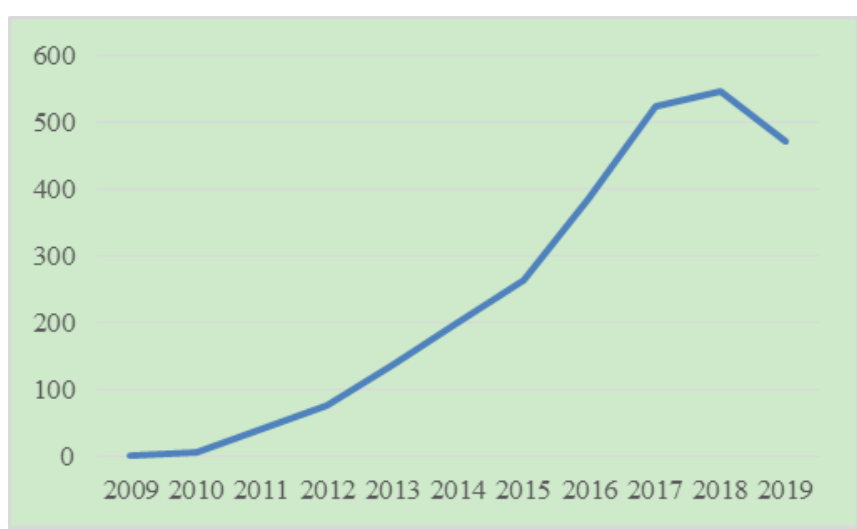

Fig. 5. The report of citation time distribution of literature.

\section{2) Topic distribution of papers with high citation volume}

The first five highly cited papers on the research topic of "robot education" were analyzed, and the specific topic contents of the five papers were as follows:

TABLE II: TOPIC DiSTRIBUTION OF PAPERS WITH HIGH CITATION VOLUME

\begin{tabular}{|c|c|c|c|}
\hline Number & Article & Subject & $\begin{array}{l}\text { Research } \\
\text { method }\end{array}$ \\
\hline 1 & $\begin{array}{l}\text { Exploring the } \\
\text { educational potential } \\
\text { of robotics in schools: } \\
\text { A systematic review }\end{array}$ & $\begin{array}{l}\text { A review of the } \\
\text { literature on robot } \\
\text { support for school } \\
\text { education }\end{array}$ & $\begin{array}{l}\text { Literature } \\
\text { review } \\
\text { method }\end{array}$ \\
\hline 2 & $\begin{array}{l}\text { The clinical use of } \\
\text { robots for individuals } \\
\text { with Autism Spectrum } \\
\text { Disorders: A critical } \\
\text { review }\end{array}$ & $\begin{array}{l}\text { A review of the } \\
\text { literature on robot } \\
\text { support for autistic } \\
\text { children }\end{array}$ & $\begin{array}{l}\text { Literature } \\
\text { review } \\
\text { method }\end{array}$ \\
\hline 3 & $\begin{array}{l}\text { Computational } \\
\text { thinking and tinkering: } \\
\text { Exploration of an early } \\
\text { childhood robotics } \\
\text { curriculum }\end{array}$ & $\begin{array}{l}\text { Robots support } \\
\text { children's } \\
\text { programming and } \\
\text { computational } \\
\text { thinking skills }\end{array}$ & $\begin{array}{l}\text { experiment } \\
\text { al method }\end{array}$ \\
\hline 4 & $\begin{array}{l}\text { Hands-on experiences } \\
\text { of undergraduate } \\
\text { students in Automatics } \\
\text { and Robotics using a } \\
\text { virtual and remote } \\
\text { laboratory }\end{array}$ & $\begin{array}{l}\text { Robots support } \\
\text { theoretical courses }\end{array}$ & $\begin{array}{l}\text { experiment } \\
\text { al method }\end{array}$ \\
\hline 5 & $\begin{array}{l}\text { Virtual laboratories for } \\
\text { education in science, } \\
\text { technology, and } \\
\text { engineering: A review }\end{array}$ & $\begin{array}{l}\text { A review of the } \\
\text { literature on robotics } \\
\text { support for science, } \\
\text { technology, and } \\
\text { engineering } \\
\text { education }\end{array}$ & $\begin{array}{l}\text { Literature } \\
\text { review } \\
\text { method }\end{array}$ \\
\hline
\end{tabular}

From 2009 to 2019 , the research topic of robot education is mainly to prove the promotion effect of the educational robot on students. Research interests include autism, computational thinking, and learning. It indicates that researchers attach great importance to the value of robots in school education. The research objects are mainly preschool students and college students. It suggests that the study of robot education for students in these two academic stages is more extensive.
In particular, the cited frequency of research on robot education in preschool children ranked the third, indicating that currently, the influence on robot education has penetrated preschool education, and it can be inferred that this influence will be further deepened. In terms of research methods, three of the five kinds of literature adopted the method of literature review, and the remaining two took the experimental method. As we mentioned before, the characteristics of the literature review itself make it easy to be cited as a highly cited paper. Both of the two papers based on experimental methods have demonstrated the positive influence of robots on computational thinking or the learning process through empirical studies, which is an important content worthy of reference and reference for subsequent studies. It reflects the current emphasis on empirical research in robot education research.

\section{3) Citation frequency distribution of papers with high citation volume}

The five papers with high citation frequency were published between 2011 and 2016. From 2011 to 2019, the citation frequency distribution of 5 highly cited papers is as follows:

TABLE III: THE Cited FReQuency Distribution OF Cited PAPERS TOP5

\begin{tabular}{lllllll}
\multicolumn{7}{c}{ FROM 2011 TO 2019 } \\
\hline \hline Number & 1 & 2 & 3 & 4 & 5 & Total \\
\hline 2011 & 0 & 0 & 0 & 0 & 0 & 0 \\
2012 & 2 & 5 & 0 & 4 & 0 & 11 \\
2013 & 8 & 12 & 0 & 12 & 0 & 32 \\
2014 & 16 & 23 & 2 & 15 & 0 & 56 \\
2015 & 15 & 30 & 6 & 10 & 0 & 61 \\
2016 & 387 & 35 & 27 & 7 & 17 & 473 \\
2017 & 524 & 56 & 37 & 24 & 13 & 654 \\
2018 & 546 & 49 & 14 & 33 & 11 & 653 \\
2019 & 471 & 28 & 22 & 22 & 6 & 549 \\
Total & 1969 & 238 & 108 & 127 & 47 & 2489 \\
\hline \hline
\end{tabular}

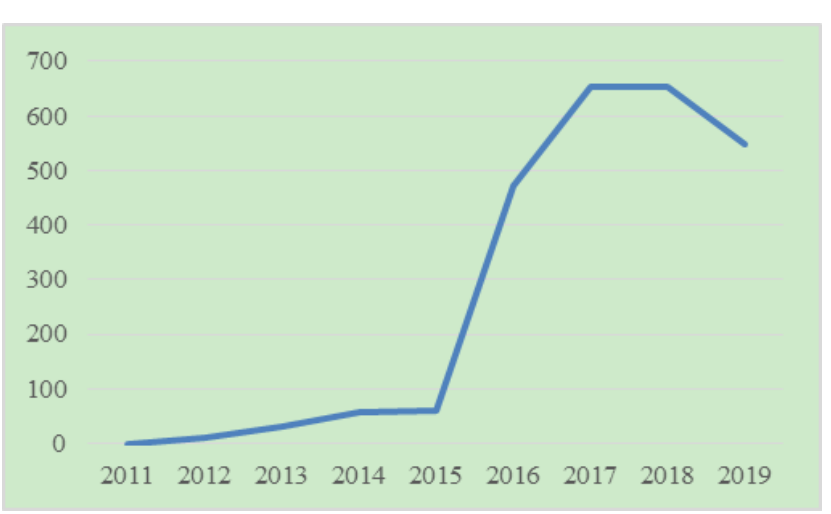

Fig. 6. Citation time distribution of high-cited papers.

The citation frequency of these five kinds of literature showed an increasing trend year by year. It was cited more frequently in 2017 and 2018 (the data in 2019 was not collected completely, thus affecting the data in 2019). The topic "robot education," which illustrates the five articles, has received more and more attention recently. People pay more and more attention to the importance of robot education. This result is also related to the continuous development of information technology. With the progress of robot technology, the possibility of robot application in the field of 
education has been dramatically improved. There are more and more educational robots suitable for education, even for young children, such as bee-bot, KIBO, LEGO, and TangibleK robots.

\section{4) Analysis of research results}

In the research of 5 kinds of literature, the role and significance of robot education and whether it has a positive impact on students' learning were certainly discussed.

TABLE IV: THE RESEARCH RESUlTS OF 5 HIGHLy CITED PAPERS

\begin{tabular}{|c|c|}
\hline The role of robot education & $\begin{array}{l}\text { Whether the results have a } \\
\text { positive impact on } \\
\text { students }\end{array}$ \\
\hline $\begin{array}{l}\text { The most common result in the literature } \\
\text { is the use of robots to help understand } \\
\text { concepts related to STEM fields. }\end{array}$ & $\begin{array}{l}\text { While in most cases, the } \\
\text { results were positive, the } \\
\text { study noted that the robots } \\
\text { showed no difference in } \\
\text { student learning }\end{array}$ \\
\hline $\begin{array}{l}\text { Some, but not all, individuals with autism } \\
\text { prefer interactive robots. }\end{array}$ & Positive \\
\hline $\begin{array}{l}\text { The TangibleK robot enables } \\
\text { kindergarten children to learn } \\
\text { computational thinking, robotics, } \\
\text { programming and problem solving. }\end{array}$ & Positive \\
\hline $\begin{array}{l}\text { A number of low-cost and flexible } \\
\text { solutions have been developed that allow } \\
\text { effective teaching of automation and } \\
\text { robotics at a reasonable cost }\end{array}$ & $\begin{array}{l}\text { This method is effective in } \\
\text { terms of students' learning } \\
\text { level and academic } \\
\text { performance }\end{array}$ \\
\hline $\begin{array}{l}\text { The possibility of robots as teaching tools } \\
\text { in primary schools to teach a second } \\
\text { language }\end{array}$ & Positive \\
\hline
\end{tabular}

Benito ti, F.B.V. found robot education can not only promote students' computational thinking and programming skills but also have a positive impact on the development of autism treatment, enhancing students' understanding of the learning process and learning a second language. In the past, the application of robotics in education has mostly focused on supporting the teaching of subjects closely related to the field of robotics, such as robot programming. However, the current research focus on educational robots is mainly related to the school curriculum, and the research results show that the use of robots as an auxiliary tool is conducive to the development of students.

\section{DISCUSSION}

Visualizing the keywords in the relevant SSCI papers in the field of robot education can help researchers discover the international development status, trends, and hotspots of this research field. By looking at the hotspot knowledge map (Fig. 5 ) in the field of robot education for nearly a decade, we can find that the hotspots of robot education research are as follows.

\section{A. Robot Education's Cultivation of Computational Thinking}

"Computational thinking" has become the most frequent word in the field of robot education in the past decade. Among them, "programming" and "computational thinking" have a high degree of relevance. Since 1960, Alan Perlis argued for the need for college students of all disciplines to learn programming and the "theory of computation" [11].
With the changes of the times, Computational thinking and coding are critical competencies in the 21 st century.

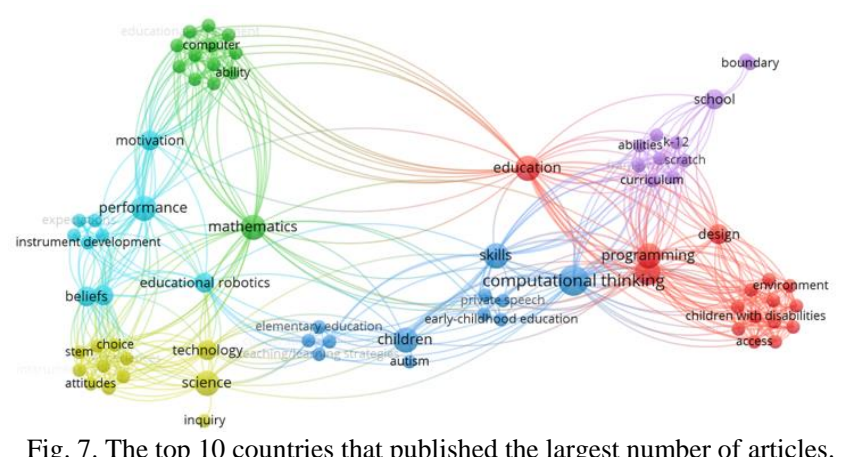

Fig. 7. The top 10 countries that published the largest number of articles.

According to Wing, "computational thinking is to solve problems, design systems and understand human behavior by using the basic concepts of computer science." [12] The essence of computational thinking is to think like a computer scientist. Jaipal-Jamani \& Angeli found that using robots for teaching not only enhances students' interest in learning new technologies but also enhances students' understanding of basic science concepts and the improvement of computational thinking skills [13]. Leonard, J. found that adopting appropriate teaching methods in robotics courses can promote the development of students' computational thinking [14].

Bers found that students can use robots, platforms, and sensors on KIBO to introduce robot teaching in preschool children's classrooms. [15] It is beneficial for children's learning of programming and has a positive impact on children's computational thinking. Children use robots. Technology has a high level of mastery in coding and computational thinking skills [16]. Besides, they can effectively integrate art, crafts, and recyclable materials into their final robotics project. The study shows that children can learn to code from an early age .Manches \&Plowman found that technology started learning at the age of three [17].

Compared with traditional forms of education, educational robots are more likely to construct a learner-centered, flexible, autonomous inquiry-based learning model, which provides a new way to develop the computational thinking ability of smaller children.

\section{B. Teaching Practice of Robot Education}

Through the visual analysis of the bibliometric method, words such as "mathematics," "science," "STEM," and "technology" were found to be more frequent. It can be seen from the above that in robot education, researchers pay more attention to the subject integration of robot teaching and the curriculum design in the field of science and engineering.

Smyrnova-Trybulska found that classes in robotics - if properly taught - will have an impact on the development of mathematical literacy and scientific-technical information and social competences. [18] STEM education is a hot topic in the current education reform in various countries, and the robot course is an effective way to promote the development of STEM education.

According to Gomoll, Hmelo-Silver, Šabanović, and Francisco and Master, Cheryan, Moscatelli, and Meltzoff, positive experience with robot education would generate 
greater interest and self-efficacy among students, particularly for girls, thus inspiring them to engage in STEM in the future [19]-[21].

In terms of educational methods, Altin \& Pedaste,(2013) evaluated the different methods used in robot teaching today and found that the teaching methods commonly used in robot education are problem-based, constructionist, and competition-based learning [22].

Smyrnova-Trybulska stresses that workshops, using kits to build and program robots, are a modern form of interdisciplinary education of children and youth. It fully illustrates the process of exploring effective teaching models, methods, and strategies for robot education. More and more researchers realize that robot education practice should not be limited to programming applications, but should focus on multidisciplinary integration and application practice.

\section{Robot Teaching Tools and Environment}

"computer," "scratch," "environment," "instrument," and other words related to robot teaching tools and environment have strong links with "education," indicating that robot education research is inseparable from related teaching tools and learning environment. Tools that effectively support robotics education and an environment that supports robotics teaching should be explored.

As open-source hardware, Arduino has the advantages of low cost and easy expansion and has become one of the important carriers for robot education in primary and secondary schools. Hsiao used Arduino and Scratch to build a Crab Robot for students to assign tasks. By connecting the conceptual knowledge of electronic components, microcontrollers, and programming design skills, the students were able to understand the subject with a higher level of comprehension [23].

Touretzky developed an open-source robot application framework called "Tekkotsu" that allows students to master robot programming quickly [24].

Han et al. explored the integration of robots with augmented reality (AR) technology to compare the interactivity and engagement of children in computer-mediated and robot-based augmented reality systems [25]. The data show that children's satisfaction, interactive participation, and media identity in robot-based augmented reality systems are significantly higher than those of computer-mediated augmented reality systems. It provided a scientific basis for the integration of robots and augmented reality technology.

At present, the related research on robot teaching tools and environment mainly tends to the design, application, and evaluation of specific tools or environments. However, the research on tools is scattered, and the promotion and continuity of tools need to be further explored. On the other hand, with the popularization of artificial intelligence in daily life, the research of robot teaching tools and the environment should keep up with the trend of technological change, so that robot education can maintain the vitality of sustainable development.
This research adopts the method of scientific measurement and analyzes related literature through the information visualization tool around the theme of "robot education." Besides, it revealed the frontiers and hotspots of current international robot education research. The research found that: 1) the hotspots of robot education mainly include the influence of robot education on students' computational thinking, 2) the teaching practice of robot education, 3) robot teaching tools, and environmental research.

With the continuous deepening of robot education research, the research focus of robot education in the period from 2009 to 2019 has paid particular attention to students'students' thinking changes and the development of robot courses. The essence of this is not only to use robots to teach programming, but to use robots as Learning objects, cognitive tools, and teaching tools.

This research result not only provides ideas and directions for researchers and practitioners in the field of robot education but also has certain enlightenment to solve a series of problems encountered in the development and practice of robot education .

\section{CONFLICT OF INTEREST}

The authors declare no conflict of interest.

\section{AUTHOR CONTRIBUTIONS}

Kaiqin Yang analyzed the data; all authors wrote the paper and had approved the final version.

\section{REFERENCES}

[1] A. G.-V. Muñoz-Repiso and Y.-A. Caballero-González, "Robotics to develop computational thinking in early childhood education," Comunicar: Media Education Research Journal, vol. 27, no. 59, pp. 63-72, 2019.

[2] G. Nugent, B. Barker, N. Grandgenett, and V. Adamchuk, "The use of digital manipulatives in k-12: robotics, GPS/GIS and programming," in Proc. 2009 39th IEEE Frontiers in Education Conference, 2009, pp. $1-6$.

[3] L. Whittier and M. Robinson, "Teaching evolution to non-English proficient students by using Lego robotics," American Secondary Education, vol. 35, Jan. 2007.

[4] D. Williams, Y. Ma, L. Prejean, M. Ford, and G. Lai, "Acquisition of physics content knowledge and scientific inquiry skills in a robotics summer camp," Journal of Research on Technology in Education, vol. 40, Jan. 2008.

[5] G. Nugent, B. Barker, and N. Grandgenett, "The effect of 4-H robotics and geospatial technologies on science, technology, engineering, and mathematics learning and attitudes," 2008.

[6] M. U. Bers, L. Flannery, E. R. Kazakoff, and A. Sullivan, "Computational thinking and tinkering: Exploration of an early childhood robotics curriculum," Computers \& Education, vol. 72, pp. 145-157, Mar. 2014.

[7] Ana andYen, "Robotics to develop computational thinking in early childhood education," Media Education Research Journal, vol. 27, pp. 63-72, 2019.

[8] S. Kucuk and B. Sisman, "Behavioral patterns of elementary students and teachers in one-to-one robotics instruction," Computers \& Education, vol. 111, pp. 31-43, Aug. 2017.

[9] F. B. V. Benitti, "Exploring the educational potential of robotics in schools: A systematic review," Computers \& Education, vol. 58, no. 3, pp. 978-988, Apr. 2012.

[10] C. S. González-González et al., "Computational thinking and down syndrome: An exploratory study using the KIBO robot," Informatics, vol. 6, no. 2, p. 25, Jun. 2019.

[11] M. Guzdial, "Paving the way for computational thinking," Communications of the ACM, vol. 51, no. 8, pp. 25-27, 2008.

[12] J. Wing, "Computational thinking," Communications of the ACM, 2006.

\section{CONCLUSION}


[13] K. Jaipal-Jamani and C. Angeli, "Effect of robotics on elementary preservice teachers' self-efficacy, science learning, and computational thinking," J Sci Educ Technol, vol. 26, no. 2, pp. 175-192, Apr. 2017.

[14] J. Leonard et al., "Using robotics and game design to enhance children's self-efficacy, STEM attitudes, and computational thinking skills," J Sci Educ Technol, vol. 25, no. 6, pp. 860-876, Dec. 2016.

[15] M. U. Bers, C. González-González, and M. B. Armas-Torres, "Coding as a playground: Promoting positive learning experiences in childhood classrooms," Computers \& Education, vol. 138, pp. 130-145, Sep. 2019.

[16] F. B. V. Benitti, "Exploring the educational potential of robotics in schools: A systematic review," Computers \& Education, vol. 58, no. 3 , pp. 978-988, Apr. 2012.

[17] A. Manches and L. Plowman, "Computing education in children's early years: A call for debate," British Journal of Educational Technology, vol. 48, p. n/a-n/a, Dec. 2015.

[18] M. Gladun et al., "Selected aspects and conditions of the use of robots in STEM education for young learners as viewed by teachers and students," Interactive Technology and Smart Education, 2017.

[19] B. Barker, G. Nugent, and N. Grandgenett, "Examining 4-H robotics and geospatial technologies in the learning of science, technology, engineering, and mathematics topics," Journal of Extension, vol. 46, Jun. 2008 .

[20] A. Gomoll, C. E. Hmelo-Silver, S. Šabanović, and M. Francisco, "Erratum to: Dragons, ladybugs, and softballs: Girls' STEM engagement with human-centered robotics," J Sci Educ Technol, vol. 25, no. 6, pp. 915-915, Dec. 2016.

[21] P. Martín-Ramos et al., "Reprint of "first exposure to Arduino through peer-coaching: Impact on students" attitudes towards programming,,"' Computers in Human Behavior, vol. 80, pp. 420-427, Mar. 2018.

[22] H. Altin and M. Pedaste, "Learning approaches to applying robotics in science education," Journal of Baltic Science Education, 2013.

[23] H.-S. Hsiao, Y.-W. Lin, K.-Y. Lin, C.-Y. Lin, J.-H. Chen, and J.-C. Chen, "Using robot-based practices to develop an activity that incorporated the $6 \mathrm{E}$ model to improve elementary school students' learning performances," Interactive Learning Environments, pp. 1-15, Jun. 2019.

[24] A. Wilson, T. Hainey, and T. M. Connolly, "Using scratch with primary school children: An evaluation of games constructed to gauge understanding of programming concepts," International Journal of Game-Based Learning, vol. 3, no. 1, pp. 93-109, 2013.
[25] J. Han et al., "Examining young children's perception toward augmented reality-infused dramatic play," Educational Technology Research and Development, 2015.

Copyright $\odot 2020$ by the authors. This is an open access article distributed under the Creative Commons Attribution License which permits unrestricted use, distribution, and reproduction in any medium, provided the original work is properly cited (CC BY 4.0).

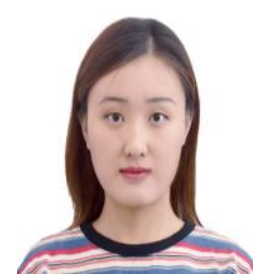

Kaiqin Yang was born in Jilin, China, on August 1, 1995. She is currently a master of education at Beijing Normal University. Her main areas of research are robotics education and STEM education. She is currently studying for a master's degree. Ms Yang did not work for the committee.

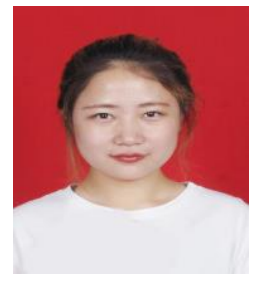

Xin Liu was born in Shanxi, China, on October 4, 1995. She is currently a master of education at Beijing Normal University. Her main area of research is the science education of preschool children. She is currently studying for a master's degree. Ms. Liu did not work for the committee.

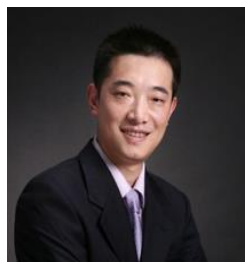

Guang Chen was born in Beijing, China. He received his $\mathrm{PhD}$ degree in Developmental and Educational Psychology from School of Psychology, Beijing Normal University.

$\mathrm{He}$ is assistant professor in the School of Educational Technology, Faculty of Education, Beijing Normal University. He is reviewer of several SSCI journals and PC member of more than 10 international conferences and workshops. He has published more than 50 journal articles, book chapters and Conference papers. His current research interest is cognitive development in information age and smart learning environments.

Dr. Chen is the leader of a National Social Science Fund project, a Beijing Municipal Commission of Education Fund project, and more than 10 other research projects. 